\title{
The habitat of crime - Random Acts of Senseless Violence from the criminological perspective
}

\begin{abstract}
This article analyses Jack Womack's Random Acts of Senseless Violence from the perspective of criminological research focusing on the correlation between criminality and the environment, i.e. the particular areas where either criminals reside, or where the crimes are committed. The ideas of the ecological school of criminology (the Chicago School), especially the studies by Shaw and McKay and their predecessors, and the so-called "Broken Windows" theory by Wilson and Kelling are introduced. The paper shows that the neighbourhoods depicted in Womack's novel might be seen as models exemplifying, albeit in a rather extreme manner, the processes presented in the aforementioned theories. This article demonstrates how the link between high crime rates and the social disorganisation of communities inhabiting specific areas may provide a possible explanation for the drastic transition of the novel's protagonist into a violent criminal.
\end{abstract}

Keywords: Jack Womack, urban ecology, New York City, alternate history, criminology.

The early 1990s were a critical time in the history of New York City's crime, with 1990 being widely reported as the year with the highest number of murders. On the 23rd of April 1991, the front page of The New York Times ${ }^{2}$ published information about a record of 2,245 killings, which was a 17.8 percent increase from the previous year (James 1991: 1), along with worrying statistics about other violent crimes. The situation seemed hopeless and called for drastic measures, which luckily were implemented; a momentous change took place within the next few years. The rates of the

1 Address for correspondence: Institute of English Studies, University of Warsaw, ul. Hoża 69, 00-681 Warsaw, Poland. Email: klara.mednis@uw.edu.pl

2 The same article aptly references Edward Shaughnessy, a sociologist, stating that "the increase in homicides reflected a surge in seemingly random violence" (James 1991: 1, emphasis added). 
seven most serious crimes dropped, a phenomenon dubbed by Franklin E. Zimring ${ }^{3}$ as "the largest documented crime decline of the twentieth century" (2012: ix). The success was proudly attributed to the effective management and introduction of new policies by Rudolph "Rudy" Giuliani, the Mayor of New York City, and William Bratton, the Commissioner of the New York City Police Department, supposedly based on the research from the influential criminological article, called "Broken Windows", written by James Q. Wilson and George L. Kelling. It should be noted that not all experts agree that the decline could be accredited solely to the authorities - there were other significant factors at play, such as the demographic shift leading to the decrease in the number of young males or the end of the drug wars caused by the imprisonment of many gang leaders (Jones 2017: 106). Yet, it could not be denied that the crime crisis was finally under control as law and order emerged victorious.

This climate of fear and the desperate need for effective policing seem to have contributed to Jack Womack's apocalyptic vision of the city in Random Acts of Senseless Violence. The novel's premise appears to be the answer to what would have happened in New York if the scale of criminal behaviour had escalated even more instead of having been contained. Published in 1993, the narrative is set in an alternate-history ${ }^{4}$ New York City from the near-future, where the social order has collapsed and crimes have become simultaneously more violent and more common - "an urban nightmare", as described by Nickianne Moody (1998: 1004). The ensuing chaos is observed through the eyes of a twelve-year-old girl, with the most inconspicuous name for a future criminal: Lola Hart. Being both the protagonist and the narrator, she introduces herself as a caring and eloquent girl, a good student from a private school, with an understanding and maturity beyond her age. However, as the story progresses, within a few short months, she becomes a brutal gang member and a bloodthirsty murderer, who wholeheartedly embraces her new, lawless life. Her extreme transition coincides with her move (due to her parents' financial problems) to a different neighbourhood, located in a part of New York that has been particularly affected by crime.

This article focuses on the real-life sociological and criminological mechanisms found in the alternate-history fictional world of Random Acts of Senseless Violence as this novel can be seen as an ideal exploration ground for some of the concepts developed by the so-called ecological school of criminology. Darko Suvin, in his essay "On the Poetics

3 In 2006, Zimring even published a book titled The Great American Crime Decline, where he studied the case in detail.

4 According to The Encyclopedia of Science Fiction, an alternate history is "an account of Earth (sometimes extending to exploration of solar-system space) as it might have become in consequence of some hypothetical alteration in history" (Stableford et al. 2019). 
of the Science Fiction Genre", where he discusses the significance of science fiction and calls it "the literature of cognitive estrangement" (1972: 372), explains that "SF takes off from a fictional ("literary") hypothesis and develops it with ... ("scientific") rigor" (1972: 374). This idea is pertinent to the analysis of Womack's novel, because even though the author describes an imaginary account of New York City's futuristic 'history', it does not exclude the validity of the processes taking place in that reality, just as in most dystopias $^{5}$. Thus, the aim of this paper is to demonstrate how Womack's work could be seen as a literary realisation of some of the theories of the ecological school of criminology, that is, pointing towards the environment of the perpetrator as one of the main causes behind their criminal activity. With the unexpected metamorphosis of the novel's young protagonist, Lola Hart, New York arises as another hero or rather villain of the story. The gruelling descriptions of the bloody acts and events happening there make the city seem as if it were a living organism, consumed by a viral disease degenerating the urban tissue and its inhabitants. Several criminological concepts and theories that might be helpful to understand the potential impact of one's surroundings will be discussed and then it will be demonstrated how Womack's depiction of the city makes it responsible for Lola's radical transformation into a criminal.

Random Acts of Senseless Violence is written in the form of Lola's diary ${ }^{6}$ and comprises five months of entries dating from the 15th of February (her twelfth birthday) to the 10 th of July. The city she describes is already succumbing to anarchy; she also mentions trouble in other parts of the United States, as well as abroad. The origins of this socioeconomic crisis are unknown to the reader. Due to the girl's unreliable narration focused on describing her everyday life, with only a few instances when she relays some

\footnotetext{
5 In Dark Horizons: Science Fiction and the Dystopian Imagination, Raffaella Baccolini and Tom Moylan, while describing the direction of dystopias written after World War II, state that "the dystopian imagination has served as a prophetic vehicle, the canary in a cage, for writers with an ethical and political concern for warning us of terrible sociopolitical tendencies that could, if continued, turn our contemporary world into the iron cages portrayed in the realm of utopia's underside" (2003: 1-2) and this view is relevant also in the discussion of Random Acts of Senseless Violence. Even though the volume does not examine Womack's work, it provides several interesting observations about the genre and is worth the attention of anyone interested in the subject.

6 This article does not discuss the implications of the choice of a diary as the form of Womack's novel, yet this topic is explored for example in Bodies of Tomorrow: Technology, Subjectivity, Science Fiction by Sherryl Vint. In one of the chapters, the critic argues, inter alia, with Joan Gordon's observations about Lola's writing from her review of Random Acts of Senseless Violence ("Two SF Diaries at the Intersection of Subjunctive Hopes and Declarative Despair") published in the Spring issue of the journal Foundation from 1998. Incidentally, the same journal also comprises two other articles analysing the novel: "The Violent Logic of Late Capitalism: Jack Womack's SF" by Douglas Barbour and "Ophelia Triumphant: The Survival of Adolescent Girls in Recent Fiction by Butler and Womack” by Michael M. Levy.
} 
rumours or fragments of (untrustworthy) television news ${ }^{7}$, it is difficult to establish accurate details of this alternate history or the scope of the violent chaos depicted in the story. Lola's accounts show that people are excessively aggressive and easily provoked; even during the commute, there are often dangerous fights and the whole population appears to behave in an uncivilized manner, regardless of their social status. The society is undergoing the process of immense radicalisation that deepens the conflicts between social classes as well as the prejudice against ethnic and sexual minorities. These phenomena, together with the nationwide economic crisis and collapse of administrative power (aggravated by the deaths of three successive presidents of the United States), lead to significant changes in urban life.

The New York that emerges from Lola's stories resembles a war zone and it gives the impression of being almost uninhabitable. The once-metropolis seems to be shrinking: new walls are constantly being built to separate the districts taken over by rioters; gangs are also claiming particular areas that, after a while, cease to be available to the general population. The girl casually comments on which parks become off-limits, not seeing anything peculiar about it since she is used to the perpetual shift of the cityscape. Moreover, this reshaping is also present in the urban nomenclature as some places acquire new names - for example, one of the most dangerous quarters in the narrator's neighbourhood, comprised of a few blocks taken over by drug dealers, smugglers and other types of street criminals, has been renamed as "the Pit". These changes are interesting to note as it appears that just as New York is altering its character along with its 'language' - and gradually disintegrating - so is Lola. Her personality transforms completely, as does her vocabulary; she loses her sense of morality that used to be visible in a great number of observations from the earlier parts of her diary, where she questioned the conduct of the authorities or the ethics of the media.

In this new cityscape, the protagonist's move to a less safe part of New York (as opposed to the Upper East Side, a rather prestigious district, where she was living at the beginning of the story) gives rise to some deeply alarming behaviour. Although she admits that she used to have some combative outbursts earlier in her life ${ }^{8}$, up until that point she had never hurt anyone nor broken the law. By the end of the novel, not only is she more aggressive and morally ambivalent, but she has become a violent gang member and a pickpocket, has severely beaten two people with her own fists and

7 Watching television is one of the main pastimes in Lola's household and the girl often mentions some fragments of the news or programmes in her diary. She comments on them, usually pointing out some inconsistencies with what she had actually seen or suspects to be the truth. The media thus appear to manipulate and censor the image of the city as they present the situation as much more optimistic. This adds to the feeling of paranoia and disinformation as well as distrust towards the state.

8 In the first grade, she started a fight with another girl during a class; and she enjoys wrestling with her younger sister. 
even killed a man with a baseball bat ${ }^{9}$. With the sudden transformation of her behaviour taking place after relocating to a new area and the focus on the city itself, Womack seems to suggest that her growing violence and criminal tendencies are related to her change of environment. This phenomenon has been the object of some criminological theories that link environmental factors to lawbreaking.

According to one of the most popular definitions coined by Edwin H. Sutherland and Donald R. Cressey, criminology is "the body of knowledge regarding juvenile delinquency and crime. It includes within its scope the process of making laws, breaking laws, and reacting to the breaking of laws" (1978: 3). Typically, the earliest criminological theories are divided into different schools that emerged around shared assumptions about criminal behaviour: the largely theoretical Classical School from the 18th century, derived from the philosophy of that time, especially utilitarianism, held a belief in the free will of criminals and the effectiveness of penalties as a deterrent to illegal acts; the Positivist School beginning in the 19th century - most famous for the biological positivist criminologist Cesare Lombroso - was occupied with the idea of scientific study of criminals, who were deemed to have some inescapable, innate features distinguishing them from the rest of the society; and, lastly, the Chicago School, rooted in sociology, analysing mostly the impact of issues such as the environment or unemployment on crime, especially in big cities. With time, there have been many other currents within criminological studies, and it is worth noting that criminology as a branch of science has an intrinsic interdisciplinary aspect. After all, it both draws from and contributes to various other fields, inter alia, sociology, jurisprudence, anthropology, psychology, psychiatry, or economics; therefore, from today's perspective, it is often impossible (and even unwise) to focus solely on one 'family' of potential causes behind lawbreaking. Yet, in this paper, as a consequence of Womack's emphasis on his protagonist's relationship with her city, Lola Hart's behaviour and the novel's depiction of New York City's crime are best analysed through the perspective of several applicable concepts and theories from the ecological approach, i.e. connected to the environment.

Human ecology as a sociological concept was developed by Robert E. Park and Ernest Burgess in the 1920s and then properly defined by Terence Morris in 1957 as "the relationships which exists between people who share a common habitat, or local territory, and which are distinctly related to the character of the territory itself" (Jones 2017: 94). The ecological school of criminology belongs to the sociological current in criminological studies and is focused on the relations between criminality and the environment

9 Lola describes most of these incidents as acts of self-defence. While some of them could be treated this way (for example beating a man unconscious after he attempted to rape her), she nevertheless behaves in an excessively violent manner. Furthermore, it is important to remember that her perspective is the only one given to the reader and that she may be presenting herself, in her diary, as more innocent than she actually is. 
of the culprits. While there were some studies of the localisation and distribution of crime in the 19th century, the 20th century was the period when more cohesive theories began to emerge, especially ones focusing on the correlation between criminal behaviour and high population density, which is characteristic for urban areas (Williams 2004: 270). There are two main groups within the studies of this subject: the first one associated with the Chicago School, concerned with the study of "high offender rate areas", meaning "the areas in which the delinquents reside", and more recent research centred around "high offence rate areas", which are understood as "areas where crimes are committed" (Williams 2004: 270).

The Chicago School, closely connected to the Department of Sociology at the University of Chicago, became prominent in the 1920s and 1930s and proposed one of the first sociological perspectives on crime. It was mostly preoccupied with the sociological analysis of the rapid development of the population of Chicago. Robert E. Park is considered to be the father of the Chicago School and his ideas strongly shaped the direction of the studies. He viewed the city "not just as a set of buildings in a particular geographic location, nor as formed by its institution, but as a living ecological environment or as a kind of social organism" (Williams 2004: 271). Ernest Burgess, another member of this school, developed Park's ideas and introduced a theory in which the city was an organism growing from its centre "in a series of concentric circles" that he subsequently divided into five zones and described their unique features (Williams 2004: 272).

When Clifford Shaw and Henry McKay conducted studies of the juvenile crime rates in Chicago in 1942, they turned their attention to the areas where the delinquents lived, as opposed to the ones where crimes were committed, thus determining which district had the highest juvenile delinquency rate. Shaw and McKay applied Burgess' model to their study and concluded that "the habitats of juvenile delinquents were usually more prevalent in inner city areas, that the social problems declined with increasing distance from the city centre, and that this picture remained true over a considerable period of time” (Jones 2017: 94). Burgess' as well as Shaw and McKay's theories have been criticised over the years by some scholars who deemed the zonal model inapplicable to other cities. However, particularly the latter theory contained some highly influential ideas, such as the model of "social disorganisation". Shaw and McKay claimed that social disorganisation - not the economic situation and poverty as such - was responsible for the collapse of the social structure. As Stephen Jones explains:

[Social disorganisation] was based on three variables: poverty, residential mobility and racial heterogeneity. Poor communities encourage social disorganisation because they do not have adequate resources to deal with their problems. The high level of mobility among the area's residents causes anonymity and no sense of community is thus able to develop. The decline of social control through the absence of common values allows a pattern of 
delinquent behaviour to develop.... Urban crime, therefore, was portrayed as resulting from the failure of the inner city environment to encourage proper integration and a sense of community for its different cultures. (2017: 95)

Social disorganisation hence is a concept that encompasses important factors that are not tied just to Burgess' zonal theory and could be applied to places that do not directly comply with his model. It is connected more to the decline of social values or certain rules that should be present in a community.

Another perspective, and an example of a study focused on the locations where crimes are committed, is provided by the so-called "Broken Windows" theory. As mentioned earlier, "Broken Windows" is an article published by James Q. Wilson and George L. Kelling in 1982, then updated by Kelling and Catherine Coles in 1996. The titular broken windows - windows that were broken during a previous act of vandalism and were not repaired afterwards - or similar signs of disorder, such as litter or graffiti, could negatively affect the processes of social control of residents of these specific areas. This means that particular neighbourhoods "descend into incivility, disorder and criminality if attention is not paid to their maintenance" (McLaughlin \& Muncie 2001: 22). Wilson and Kelling explained that:

An unrepaired broken window signals to law-abiding and criminals alike that no one cares. Gradually other windows in the building will be smashed and this will reinforce the sense that the local community and the authorities have relinquished ownership and that disorder is tolerated. For them, petty disorderly acts, which are not necessarily breaches of the criminal law, trigger a chain reaction that undermines community safety and paves the way for serious criminality. If a neighbourhood or a street is perceived to be increasingly disorderly and unsafe people modify their behaviour accordingly. (McLaughlin \& Muncie 2001: 22)

This indicates that people will be afraid of living or passing through these places and only the ones who cannot afford to leave their homes behind will remain, namely those most vulnerable. In time, these areas will be taken over by individuals involved in various illegal activities, e.g. drug dealers or gang members. So-called street criminals will introduce new sets of rules in these neighbourhoods, enabling the flourishing of their illicit businesses in the area.

Wilson and Kelling's study was a milestone in the search for an improved and more effective method of fighting crime in big cities. The researchers proposed their own ideas for new policies, but they were also an inspiration for others. The strategies used by the New York City police in the 1990s are often deemed to be an extension of some of the concepts from "Broken Windows", such as the controversial "zero tolerance" policy. It "returned officers to street patrolling and mandated them to target the broad 
spectrum of low level misconduct and widespread anti-social behaviours which made the city feel unsafe and disorderly" (McLaughlin \& Muncie 2001: 23) but its practical application was often criticised for being unjust and unnecessarily strict. Nevertheless, the crime statistics improved.

While the crime rates in the real New York City declined, in Womack's version of the city, the violence escalated, leading to the collapse of social order. Considering the fact that the novel does not provide any information about the origins or timescale of the disruption of the norms, it can be assumed that, at this point of the alternate history, the degree of disintegration is so high that the rapid changes in the society or urbanscape should not be seen as extraordinary. In such a hostile and unstable environment, longestablished social processes stop following old patterns, which leads to more extreme consequences than typically. This hypothesis might explain why the city has drowned in anarchy so drastically and why Lola's behaviour has altered so much during a rather short period of time (five months).

What is more, from what the girl recounts, urban areas are smothered by anomie. The social structure is crumbling, and there are problems in New York and some other major cities caused by rioting people and the army brutally quelling them. The financial crisis has led to widespread poverty, unemployment and bankruptcies. What Lola describes is not just violence perpetrated by people on the streets but state violence as well, which contributes to the prevalence of crime. Moreover, aggression and abuse are omnipresent on television, not just in the news but also in the public service announcements and very graphic commercials; all of this results in some kind of general immunity to cruelty. Citizens have stopped reacting to barbarous behaviour on the streets, normalising such acts as setting people on fire, physical assault and extreme verbal abuse as a part of the urban life. Applying Shaw and McKay's theory of social disintegration on a large scale might be useful to explain this situation as the problems ascribed by the scholars to the inner city appertain to a much broader area in Lola's reality. When poverty, the collapse of social bonds among communities, fear and general hostility towards each other become city- or even nation-wide issues instead of being limited to a particular zone, then the whole structure is rendered vulnerable, and order cannot be maintained. The rule of law is over. The only remaining defence mechanism is crime: it is either you or them.

Due to the debts of Lola's parents and their inability to find any well-paying jobs on the current market, her family is forced to move to a new neighbourhood located near Columbia University's campus, just south of Harlem. After the move, the girl encounters a new dangerous world with a different set of rules, full of organised gangs, abuse 
(sexual abuse in particular ${ }^{10}$ ), and violence from other inhabitants. Moreover, the narrator describes acts of state violence, emanating from the deeply crippled system: soldiers and other law enforcers who exploit their power over the members of that community. The way that Lola and people around her are devised implies that the new neighbourhood and the social disorganisation festering in this place are the main reasons for her transformation. Earlier, she did not have any problems with socialising or maintaining standards of acceptable behaviour, and the author seems to dismiss any speculations that perhaps her upbringing or education could be the rationale behind the protagonist's violence. The girl does not appear to idealise her parents when she portrays them in her diary - she has no reservations about criticising their financial decisions or other weaknesses. Hence, there is no reason to mistrust the girl when she describes her family life and childhood up to that moment as having been a happy one. There is no indication of any earlier distress or trauma that could have affected her. She comes from a liberal and academic background: her mother used to be an English professor at New York University who later worked as a teacher; her father is a screenwriter whose scripts are deemed too sophisticated for the studios. She likes going to school, studies diligently and enjoys reading. Nothing in her life before the move suggested that in a few months' time she would revel in murder.

However, all this changes upon arriving at her new home. Lola's first glimpse of her new neighbourhood does not bode well:

'It's a slum' Boob [her younger sister] said and Daddy said it wasn't, it was student housing.... The buildings along Broadway where the campus is are all being strung up with barbed wire because the crime is so bad and the people at the gate looked like real policemen with machine guns like at the airport. (Womack 2013: 51)

What is more, just after arriving there for the first time with their things, some of their possessions are stolen. It appears that the dilapidated housing estates, most of them already occupied by local gangs and drug lords, only invite more crime, exactly as postulated in Wilson and Kelling's "Broken Windows" theory. In this new place, there is no law because neither the police nor the army intervene or protect anyone unless they have orders to pacify the rioters or raid apartments. All the nearest buildings seem to be model examples of the lack of social control:

10 Shortly after the move, when Lola decides to wear summer clothes during extremely hot weather, she is catcalled and then approached by a band of boys who surround her and start to assault her. If her friends from the girl gang had not intervened in time, the boys would have forcibly taken her to the nearest park, as they suggested, and raped her. Later in the story she is again attacked and molested by a man and saved by her friends. 
The place is bad enough from the outside but you should see the lobby. There were bullet holes in the glass in the doors and half the lights were broken out.... People wrote graffiti all over the walls. Half the elevators weren't working and had their doors pulled away like somebody tried to get in them with a can opener. Five or six men were sitting in broken chairs drinking beer and staring at us.... The windows at the end were broken out. (Womack 2013: 143)

Soon after the move, Lola realises that she has entered new territory and that her best chance of surviving is to try to find allies. Therefore, she befriends members of the girl gang called "Death Angels". Earlier in the novel, she had encountered a similar gang of teenage girls and was appalled by their cruelty. Now, however, she seeks their approval and permission to officially join them. The girls - Iz in particular - help her by showing her around the neighbourhood, issuing warnings about certain areas and explaining how to get by: when she is attacked, she has to counter-attack. The protagonist gradually adapts and grows accustomed to her gang's often illegal acts. Although she feels guiltridden after witnessing her new friends pickpocketing cooperatively for the first time, later, she accepts this behaviour and even becomes a more active participant in the operation. Furthermore, when her family's financial situation drastically deteriorates, Lola has no scruples about stealing money from commuters on her own. Subsequently, she starts to commit crimes not just to survive in her new reality, but because she wants to. Lawbreaking exhilarates her and her conscience degenerates to such an extent that, having killed a man, her only regret is that the joy she feels after the murder does not last longer.

It should be noted that while Iz also lives near Lola's neighbourhood and often breaks the law, she is not as aggressive as the protagonist. She seems less negatively affected by her surroundings, probably because she is African American and has been living in a racially homogenous part of the neighbourhood with her family for a long time. Moreover, she is a Christian who, despite claiming that she is not very religious, still goes to church with her relatives and, therefore represents someone belonging to a community with strong social bonds. Besides, the puzzling problem with Lola is not the fact that she is growing as violent as the other gang members who have lived for a longer time in the area, but that she has surpassed them by proving to be more brutal ${ }^{11}$, and her crimes are more serious. It is probable that the girl is an easier 'victim' of the processes of social disorganisation because she is a newcomer to this neighbourhood. She feels as if she does not belong anywhere, which aligns with the findings of sociological research about people living in transitional zones. Lola's apartment belongs to an old Columbia University housing complex, so the students and other inhabitants of these buildings probably do not stay there for long. This space constitutes a much more

11 Lola actually shocks the other girls with her violent outbursts and is soon nicknamed "Crazy Lola". By the end of the novel, they stop associating with her because of her excessively aggressive behaviour. 
transitional zone than where Iz lives - a block of flats inhabited by more racially homogeneous families who spend time together as a community. The protagonist's disadvantage comes also from the fact that she gradually loses people close to her: all her friends and family. Her father dies, her sister becomes catatonic and then leaves to live with an aunt in California and even her mother is admitted to hospital for some time. The loss of these bonds and the lack of meaningful social interactions also impact the girl's susceptibility to outside influences.

Another example of an area potentially fitting the "Broken Windows" theory is the aforementioned "Pit":

'Pit's nearly the worst of worst.... This the Free Enterprise Zone unofficial' Jude said as we crossed the street. In the next block were thousands of people standing around drinking and arguing and huddling in little groups. We edged lightfoot through them so they wouldn't notice us but I don't think they would have anyway they were so busy buying and selling. A row of trucks covered with graffiti was parked in a vacant lot and people sold TVs and VCs and stereos from them. Men wearing hoods over their heads and with rifles slung around their shoulders loaded brown paper packages into the trunks of cars.... Two men lifted a blanket off the back of a pickup truck showing all sorts of big and small guns underneath.... There were a lot of police cars around but the cops were busy buying and selling too all the way to St Nicholas Avenue. (Womack 2013: 150-52)

This appears to be exactly the kind of area where criminals 'push out' all the lawabiding inhabitants and introduce their own rules. A whole neighbourhood turns into a lawless zone, a home for all kinds of illegal activities, where even the police contribute to the illicit businesses.

Another interesting correlation between Lola's behaviour and her surroundings is the fact that the girl's most violent outbursts seem to be linked to the brutal social climate of the city. The first one happens immediately after witnessing an outbreak of riots and vindictive police attacks on civilians. Another occurs after a protest that yet again turns into warlike street fighting. These tensions are closely connected with the suffocating city as there are too many people in the shrinking, barely inhabitable areas. The streets are suddenly too narrow and every demonstration, every congregation, turns into a bloody battle over territory. Social order collapses as the residents of such a place are often bound to succumb to aggression.

When the social structure disintegrates in a city, its whole urbanscape is altered; the habitable land shrinks. New York City turns into a conflict zone:

Washington Heights and Inwood look like I expected all torched and blasted except round City College and Columbia Presbyterian. They have those rounded bout with razorwire 
and soldiers. Hardly any businesses are left anywhere except liquor stores and bodegas.... Army's got the streets lined with tanks even though they're not supposed to let them in and everywhere you look there's thousands of soldiers armed and itchy. They're building another wall down the middle of Dyckman Street in Inwood. (Womack 2013: 182)

With widespread unemployment, inflation and danger on the streets, the old institutions, establishments or shops lose their purpose and become redundant. Trade moves to locations like "the Pit" and people need to look for money elsewhere. In such circumstances, their language does not remain passive and the reader learns this from Lola's changing vocabulary. Along with the evolution of names of certain places, regular words that are no longer applicable gain new meaning. When one is stealing money, it is called "banking". The omnipresent aggression and anomie lead to a kind of numbing of ethics that results in euphemisms replacing terms that once used to be serious or malevolent: pickpocketing is "boosting", attacking is "yoking", killing is "exing". It is almost as if with a different name, these actions become something less atrocious than in days gone by.

The more time Lola spends on the streets, the more erratic and aggressive her language becomes, as does her behaviour. Following in the footsteps of the other girls from the gang, she starts using the abstract names for the crimes she commits. Long-established grammatical rules vanish; new words ${ }^{12}$ are created where nouns are used as verbs and vice versa: "Weez ideas that somebody like you think natural you better than her" (Womack 2013: 125), “If she blade you' she started to say and stopped” (Womack 2013: 126), "Word me Blood I want knowin” (Womack 2013: 153). She never mentions the change of her manner of speaking in her diary and perhaps she is unaware of it, but the reader is able to estimate the progression of the deterioration of Lola's ethics in the subsequent degeneration of her idiolect. As Veronica Hollinger, who compared the languages in both Random Acts of Senseless Violence and A Clockwork Orange, explains:

In Random Acts, however, language does more than simply help to construct a future scenario. Equally important is the way in which the gradual shift in the discourse of Lola's diary entries, from 'ordinary' middle-class English to the language of youth subcultures and street gangs, tracks the gradual breaking down of Lola's personality. (2000: 87)

12 The topic of changing vocabulary in Random Acts of Senseless Violence as well as in other violent dystopian realities is further investigated by Roger Luckhurst in "Going Postal: Rage, Science Fiction, and the Ends of the American Subject", which is one of the chapters of Edging into the Future: Science Fiction and Contemporary Cultural Transformation, edited by Veronica Hollinger and Joan Gordon. 
The Lola Hart that introduced herself on the day of her twelfth birthday ceases to exist. The lawless chaos in the broken city, the unjust abuse that she experiences, as well as the conditions in her neighbourhood - especially its inhabitants' acceptance of crime and social disorganisation - have contributed to the girl's radical transition into a bloodthirsty criminal. She discovers not only her potential for violence, but even an appetite for it and the power that might come from brutal acts. Once, she might have questioned the ethics of such delinquent behaviour; now, however, she is the one committing serious crimes and enjoying it. She willingly accepts her new fate and renounces values associated with the rule of law or social order.

Nearing the end of her diary, she writes: "The world brutalizes however you live it whatever you do" (Womack 2013: 192), which shows her disillusionment with the system. She chooses the life of crime in order to survive: "If we're [Lola and her mother] not going to wind up street housing then I'll have to do whatever funding essentials to keep the bank open. I'm no burger pusher.... It's unreasoned Anne it's unfair but there's naught to do it's mapped out now" (Womack 2013: 221). While reading such fragments, it is difficult to remember that Lola is just twelve years old. She gives the impression of being an adult, not only because of her vicious actions but also due to her acceptance of responsibility. After her mother's health deteriorates past being able to work at all, the protagonist realises that she is now the one in charge of earning money, yet she refuses to do jobs that she considers to be beneath her. It is arguable that this reasoning leads to her resorting to a life of crime. At this point, she already knows how to pickpocket wallets; robbery might follow. This alternate-history New York City lacks any authorities that could stop her from taking such a step. It seems unlikely that the police would actually arrest her; as a matter of fact, given their belligerence and abusive tendencies, even towards innocent people, it is more probable that a policeman or a solider would end up taking her life. Such is the reality of areas with omnipresent crime - people living there lose all hope of having justice served. For Lola, power, especially one executed in a brutal and merciless manner, means security, not unlike her strategy of attacking first, which acts as a shield protecting her from the hostile environment infested with injustice and predators. She uses violence as a deterrent to others, in an effort to survive and live unmolested, by her own rules.

Lola's final entry is a goodbye, not only to Iz (for whom she has developed romantic feelings) but also to her old life in general. She writes: "We've walled apart not for Jude not cause I love love her but cause I crossed over and you can't come here less you want. Night's darkened full now and I spec I'm finally set to ride. Take me street take me" (Womack 2013: 222). The idea of "crossing over" is particularly interesting in this discussion of the relation between the girl and the city because it could be understood as her crossing to yet another neighbourhood, even worse this time. She wants "the street to take her", which means that this is what she associates her life with now. At the 
very end, she writes almost a warning to other people about herself, which seems to be also some sort of statement announcing the new person that she has become.

Random Acts of Senseless Violence depicts New York City as a living organism that is infested with violence beyond any hope of recovery. The disease spreads through the city's bloodlines and causes outbreaks of crime, in turn breeding new criminals. Social disorganisation and the tolerance of disorder foster lawbreaking. Despite the fact that nowadays the early ecological theories are often criticised for too many oversimplifications - especially for prejudiced targeting of certain people or areas - and that pointing to a perpetrator's neighbourhood or the place where they committed a crime as the only reason for their actions would be too short-sighted and unfair, the legacy of the concepts born out of the Chicago School of criminology is undeniable. Even though some hypotheses may no longer be as applicable as they were believed to be in past decades, many ideas are still useful. The introduction of the "Broken Windows"-inspired policy in New York City in the 1990s could be an apt example of this. An alternate-history work of fiction like Random Acts of Senseless Violence seems to be a perfect 'lab subject' for the above-mentioned theories as is the nature of science fiction texts, according to Suvin. As it was demonstrated earlier, Womack constructed Lola's story in such a way that it almost excluded other potential causes for her criminal behaviour. The protagonist's transformation is connected so deeply with New York City - they disintegrate and succumb to violence at the same pace - that the city's influence cannot be overlooked.

\section{References}

Baccolini, R. \& Moylan, T. (eds.). 2003. Dark Horizons: Science Fiction and the Dystopian Imagination. New York: Routledge.

Barbour, D. 1998. The violent logic of late capitalism: Jack Womack's SF. Foundation 72 (Spring 1998): 20-33.

Gordon, J. 1998. Two SF diaries at the intersection of subjunctive hopes and declarative despair. Foundation 72 (Spring 1998): 42-48.

Hollinger, V. 2000. 'A Language of the Future': Discursive Constructions of the Subject in A Clockwork Orange and Random Acts of Senseless Violence. In: A. Sawyer \& D. Seed (eds.), Speaking Science Fiction. Dialogues and Interpretations, 82-95. Liverpool: Liverpool University Press.

James, G. 1991. New York killings set a record, while other crimes fell in 1990. The New York Times 23 April 1991: 1.

Jones, S. 2017. Criminology. Oxford: Oxford University Press.

Levy, M. M. 1998. Ophelia triumphant: the survival of adolescent girls in recent fiction by Butler and Womack. Foundation 72 (Spring 1998): 34-41.

Luckhurst, R. 2002. Going Postal: Rage, Science Fiction, and the Ends of the American Subject. In: V. Hollinger \& J. Gordon (eds.), Edging into the Future: Science Fiction 
and Contemporary Cultural Transformation, 142-156. Philadelphia: University of Pennsylvania Press.

McLaughlin, E. \& Muncie, J. (eds.). 2001. The Sage Dictionary of Criminology. London: SAGE Publications.

Moody, N. 1998. Social and temporal geographies of the near future: music, fiction and youth culture. Futures Vol. 30 No. 10, December 1998: 1003-1016.

Stableford, B. M., Wolfe, G. K. \& Langford, D. 2019. Alternate History. In: J. Clute, D. Langford, P. Nicholls \& G. Sleight (eds.), The Encyclopedia of Science Fiction. London: Gollancz, updated 30 July 2019. http://www.sf-encyclopedia.com/entry/alternate_history (2 September 2019).

Sutherland, E. H. \& Cressey, D. R. (eds.). 1978. Criminology. Philadelphia: J. B. Lippincott. Suvin, D. 1972. On the poetics of the science fiction genre. College English, Vol.34 No.3 (Dec. 1972): 372-382.

Vint, S. 2007. Jack Womack and Neal Stephenson: The World and the Text and the World in the Text. Bodies of Tomorrow: Technology, Subjectivity, Science Fiction, 138-170. Toronto: University of Toronto Press.

Williams, K. S. 2004. Textbook on Criminology. Oxford: Oxford University Press.

Womack, J. 2013. Random Acts of Senseless Violence. London: Gollancz.

Zimring, F. E. 2012. The City That Became Safe: New York's Lessons for Urban Crime and its Control. New York: Oxford University Press.

$$
* * *
$$

Klara Mednis is a doctoral student in the British Literature Department of the Institute of English Studies at the University of Warsaw. Her research focuses on unreliable narrators in 20th and 21st century British and American fiction, feminist studies, contemporary retellings of Shakespeare's plays and interdisciplinary approaches to literature involving psychology and criminology. 